\title{
Aktivitas Siswa SMP dalam Proses Pembelajaran Kooperatif pada Mata Pelajaran Matematika
}

\author{
Luluk Fatimah*, Abdul Shofi \\ SMP Negeri 35 Surabaya, Jalan Rungkut Asri No. 22, Rungkut, Surabaya, Jawa Timur, Indonesia \\ * E-mail: lu2kfatimah@ gmail.com
}

\begin{abstract}
Abstrak
Pembelajaran Kooperatif merupakan model pembelajaran yang menonjolkan aktivitas siswadalam menyelesaikan masalah. Model pemeblajaran ini juga sering digunakan pada mata pelajaran yang dianggap sulit untuk dipahami sehingga dapat digunakan untuk meningkatkan proses dan hasil be lajar. Penelitian ini bertujuan untuk mengetahui aktivitas siswa SMP dalam proses pembelajaran kooperatif pada mata pelajaran matematika. Penelitian ini merupakan penelitian deskriptif. Pembelajaran dilaksanakan pada bulan Agustus 2019, semester ganjil tahun ajaran 2018/2019 dengan sasaran sebanyak 38 siswa kelas 9D SMP Negeri 35 Surabaya. Hasil penelitian menunjukkan bahwa aktivitas siswa SMP dalam proses pembelajaran kooperatif sangat baik, dengan persentase $88,6 \%$. Berdasarkan hal tersebut, dapat disimpulkan bahwa aktivitas siswa SMP dalam proses pembelajaran kooperatif pada mata pelajaran matematika termasuk ke dalam kriteria sangat baik.
\end{abstract}

Kata Kunci: kooperatif, pembe lajaran, matematika

\section{Abstract}

Cooperative learning is a learning model that emphasize student activity in solving problems. This learning model is also often used in subjects that are considered difficult to understand so that it can be used to improve the proccess and learning outcomes. The objective on this study is to find out the students' activity during cooperative learning process in mathematics class. It is a descriptive study. The learning process was done on August 2019, with 38 students on the grade 9D, 35 State Junior High School Surabaya. Results show that students gave positive activities during the learning process, with $88.6 \%$ on percentage. In conclusion, the students' activity during the cooperative learning process in mathematics class is very good.

Keywords: cooperative, learning, mathematics

\section{PENDAHULUAN}

Belajar adalah seperangkat proses kognitif yang mengubah sifat stimulasi lingkungan, melewati pengolahan informasi, menjadi kapabilitas baru. Tujuan belajar yang eksplisit diusahakan untuk dicapai dengan tindakan instruksional, lazim dinamakan instructional affects, yang biasa berbentuk pengetahuan dan keterampilan (Rofiq, 2010).

Berdasarkan hasil wawancara terhadap beberapa siswa SMP Negeri 35 Surabaya, matematika adalah salah satu mata pelajaran yang dianggap paling sulit oleh para siswa SMP karena materinya berisi banyak simbol, rumus, dan perhitungan. Selain itu, para siswa juga menginginkan adanya pembelajaran yang bervariasi dan menyenangkan pada mata pelajaran matematika.
Pemilihan materi didasarkan oleh hasil wawancara dan observasi pada siswa subyek penelitian yang menunjukkan bahwa sebagian besar siswa merasa kesulitan memahami materi bilangan pangkat dan akar. Selain itu, siswa juga menemukan kesulitan dalam membedakan dan membandingkan bilangan pangkat dan bilangan akar, serta menyebutkan contoh serta mengaitkan konsep tersebut dalam kehidupan sehari-hari.

Penentuan model pembelajaran yang tepat dan sesuai dengan materi yang diajarkan sangat penting untuk mencapai tujuan pembelajaran. Meskipun tujuan pembelajaran telah dirumuskan dengan baik dan materi yang dipilih sudah tepat, jika model pembelajaran yang digunakan kurang memadai mungkin tujuan yang diharapkan tidak tercapai dengan baik. Jadi, model pembelajaran merupakan 
suatu komponen pembelajaran yang sangat penting dan sangat menentukan dalam keberhasilan proses pembelajaran.

Model pembelajaran yang baik seharusnya mengutamakan interaksi guru dengan peserta didik, serta interaksi antar peserta didik yang akan membentuk sinergi yang saling menguntungkan semua anggota (Anita, 2008). Supaya pembelajaran matematika dapat membuahkan hasil yang optimal, hendaknya guru sebisa mungkin untuk dapat memilih model pembelajaran yang mampu melibatkan peserta didik berperan aktif dalam proses pembelajaran.

Oleh karena itu, bagaimanapun tepat dan baiknya bahan ajar matematika yang ditetapkan belum menjamin akan tercapainya tujuan pendidikan, dan salah satu faktor penting untuk mencapai tujuan tersebut adalah proses pembelajaran yang lebih menekankan pada keterlibatan peserta didik secara optimal.

Pembelajaran kooperatif (Cooperative Learning) merupakan salah satu bentuk model pembelajaran sosial yang didasarkan pada teori belajar konstruktivisme. Beberapa ahli pendidikan berpendapat bahwa model pembelajaran kooperatif tidak hanya unggul dalam memudahkan peserta didik memahami dan menerapkan konsep, namun juga dalam mengembangkan kemampuan kerjasama, berpikir kritis dan sikap percaya diri yang dimiliki oleh peserta didik (Nurhadi, 2003).

Pembelajaran kooperatif adalah model pembelajaran yang berfokus pada penggunaan kelompok kecil peserta didik untuk bekerjasama dalam memaksimalkan kondisi belajar demi tercapainya tujuan belajar. Pembelajaran kooperatif dapat dijadikan sebagai alternatif model pembelajaran yang menarik yang dapat mencegah timbulnya keagresifan dalam sistem kompetisi dan keterasingan individual peserta didik tanpa mengorbankan aspek kognitif yang dimiliki peserta didik tersebut (Rofiq, 2010).

Menurut Jasmine (2007) komponen dasar pembelajaran kooperatif antara lain, pertama semua anggota kelompok tidak perlu bekerja sama menyelesaikan tugas, karena tugas dan aktivitas dirancang sedemikian rupa agar masing-masing anggota tidak menuntaskan bagiannya sendiri. Kedua, kelompok yang dibentuk sebaiknya heterogen, sehingga terdapat keseimbangan kemampuan dalam kelompok. Ketiga, aktivitas pembelajaran hendaknya dirancang sedemikian sehingga siswa dapat berkontribusi dengan baik dan setiap kelompok dapat dievaluasi atas kinerjanya. Keempat, setiap kelompok harus mengetahui tujuan akademik maupun sosial, agar siswa mengetahui apa yang diharapkan dalam pembe lajaran.

Sehingga dalam pelaksanaan pembelajaran kooperatif, setiap kelompok dibentuk secara heterogen, setiap anggota kelompok bekerja sama, setiap kelompok mengetahui tujuan pembelajaran, serta guru perlu merancang aktivitas pembelajaran.

Model pembelajaran kooperatif dinyatakan sebagai model pembelajaran yang mengutamakan eksistensi kelompok. Setiap siswa dalam kelompok memiliki tingkat kemampuan yang berbeda (tinggi, sedang, dan rendah). Model pembelajaran ini mengutamakan kolaborasi dalam memecahkan masalah untuk menerapkan pengetahuan dan keterampilan untuk mencapai tujuan pembelajaran (Arends, 2012).

Tujuan utama dari pelaksanaan pembelajaran kooperatif adalah untuk meningkatkan aktivitas siswa dalam menyelesaikan tugas-tugas akademisnya, meningkatkan toleransi dan penerimaan siswa terhadap perbedaan ras, budaya, kelas sosial, dankemampuannya, dan mengajarkan keterampilan kerjasama dan kolaborasi kepada siswa (Martati, 2010).

Kelebihan dari penerapan pembelajaran kooperatif ini dapat memberikan peluang kepada siswa agar siswa mampu memberikan pendapat, mampu membahas suatu pandangan, dan pengalaman yang diperoleh oleh siswa untuk merumuskan pandangan kelompok (Isjoni, 2010). Dengan melibatkan semua siswa seacara langsung, tingkat pemahaman dan penguasaan dapat diuji, mengembangkan cara berfikir, memperoleh kepercayaan diri, dan mengembangkan sikap sosial (Trianto, 2009). Kekurangan atau kelemahan pembelajaran kooperatif belum pernah dilaporkan memiliki pengaruh negatif. Sehingga model-model yang ada dalam pembelajaran kooperatif terbukti lebih unggul dalam hal peningkatan hasil belajar siswa.

Hasil belajar merupakan tujuan akhir pembelajaran yang ditentukan oleh beberapa hal antara lain faktor internal dan faktor eksternal (Slameto, 2003). Selain itu, Syah (2002) berpendapat bahwa selain faktor 
internal dan faktor eksternal juga terdapat faktor pendekatan belajar yang dapat mempengaruhi hasil belajar. Pembelajaran kooperatif dapat mempengaruhi aktivitas belajar dan pada akhirnya akan berpengaruh terhadap hasil belajar.

Pada penelitian ini tidak difokuskan pada hasil belajar, akan tetapi lebih pada aktivitas belajar siswa pada pembelajaran kooperatif yang dimungkinkan dapat berpengaruh terhadap hasil belajar. Adapun tujuan dari penelitian ini adalah untuk mengetahui aktivitas siswa SMP selama proses pembelajaran kooperatif pada mata pelajaran matematika.

Sehingga, dari uraian diatas dirasa perlu untuk melakukan penelitian tentang aktivitas siswa SMP dalam proses pembelajaran kooperatif pada mata pelajaran matematika.

\section{METODE}

Penelitian ini merupakan penelitian deskriptif. Subyek penelitian ini adalah 38 siswa kelas 9D SMP Negeri 35 Surabaya, yang terdiri atas 17 laki-laki dan 21 perempuann. Pembelajaran kooperatif diajarkan pada materi bilangan pangkat dan akar, mata pelajaran matematika kelas 9. Penelitian ini dilaksanakan pada bulan Agustus, tahun ajaran 2018/2019.

Aktivitas siswa selama proses pembelajaran kooperatif pada mata pelajaran matematika diukur dengan teknik pengamatan. Hasil pengamatan tersebut diperoleh dari instrumen lembar pengamatan aktivitas siswa.

Persentase aktivitas siswa dihitung menggunakan rumus sebagai berikut:

Keaktifan siswa $(\%)=\frac{\sum \mathrm{S}}{\sum \mathrm{T}} \times 100 \%$

Keterangan:

$$
\begin{aligned}
\sum S= & \text { Jumlah siswa yang melakukan aspek } \\
& \text { tahapan } \\
T & =\text { Jumlah total seluruh siswa. }
\end{aligned}
$$

Persentase aktivitas siswa kemudian diinterpretasikan menggunakan kriteria interpretasi sebagai berikut:

Tabel 1. Kriteria penilaian keaktifan siswa

\begin{tabular}{lcc}
\hline No & Persentase & Kategori \\
\hline 1. & $0-19 \%$ & Tidak baik \\
2. & $20-39 \%$ & Kurang baik \\
3. & $40-59 \%$ & Cukup baik \\
4. & $60-79 \%$ & Baik \\
\hline
\end{tabular}

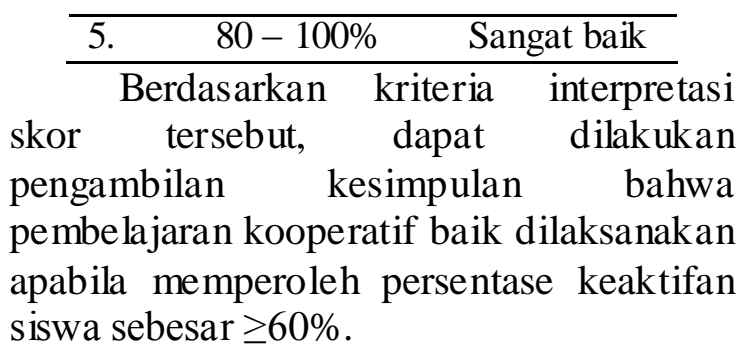

\section{HASIL DAN PEMBAHASAN}

Hasil penelitian yang mengukur keaktifan siswa selama proses pembelajaran kooperatif pada mata pelajaran matematika disajikan pada Tabel 2.

Tabel 2. Keaktifan siswa pada proses pembelajaran kooperatif

\begin{tabular}{llc}
\hline $\begin{array}{l}\text { No } \\
\text {. }\end{array}$ & Tahapan pembelajaran & $\begin{array}{l}\text { Persentase } \\
\text { keaktifan }\end{array}$ \\
\hline 1. & Present goals and set & 100.0 \\
2. & $\begin{array}{l}\text { Present information } \\
\text { 3. }\end{array}$ & 92.1 \\
& $\begin{array}{l}\text { Organize students into } \\
\text { learning teams }\end{array}$ & 78.9 \\
4. & Assist team work and & \\
& students & 84.2 \\
5. & Test on the materials & 94.7 \\
6. & Provide recognition & 81.6 \\
& Total persentase & $\mathbf{8 8 . 6}$ \\
\hline
\end{tabular}

Berdasarkan hasil yang ditunjukkan pada Tabel 2 dan Gambar 1 tersebut, dapat dikatakan bahwa siswa aktif selama proses pembelajaran kooperatif pada mata pelajaran matematika, materi bilangan pangkat dan akar.

Selain itu, dari Tabel 2 juga dapat disimpulkan bahwa keaktifan siswa paling tinggi adalah pada kegiatan paling awal yaitu penyampaian tujuan pembelajaran. Sedangkan kegiatan ketiga yaitu mengorganisasikan dalam kelompok memperoleh persentase paling rendah.

Model pembelajaran kooperatif adalah rangkaian kegiatan belajar yang dilakukan oleh siswa dalam kelompok-kelompok tertentu untuk mencapai tujuan pembelajaran yang telah dirumuskan.

Pembelajaran kooperatif (Cooperative Learning) merupakan salah satu bentuk model pembelajaran yang mendominasikan aktivitas berbasis sosial yang didasarkan pada teori belajar konstruktivisme. Beberapa ahli pendidikan berpendapat bahwa model pembelajaran kooperatif tidak hanya unggul dalam memudahkan peserta didik memahami dan menerapkan konsep, namun juga dalam 
mengembangkan kemampuan kerjasama, berpikir kritis dan sikap percaya diri yang dimiliki oleh peserta didik (Nurhadi, 2003).

Adapun model pembelajaran kooperatif memiliki berbagai jenis atau tipe. Namun secara umum, kekhasan yang ditonjolkan pada model pembelajaran kooperatif adalah membentuk karakter siswa yang mampu bekerja sama dan berkolaborasi. Selain itu, model pembelajaran kooperatif juga mampu muka, komunikasi intensif antar siswa, dan evaluasi proses kelompok.

Dalam cooperative learning siswa tidak hanya mempelajari materi saja tetapi siswa atau peserta didik juga harus mempelajari keterampilan-keterampilan khusus yang disebut keterampilan kooperatif. Keterampilan kooperatif ini berfungsi untuk melancarkan hubungan kerja dan tugas. Peranan hubungan kerja dapat dibangun dengan membangun

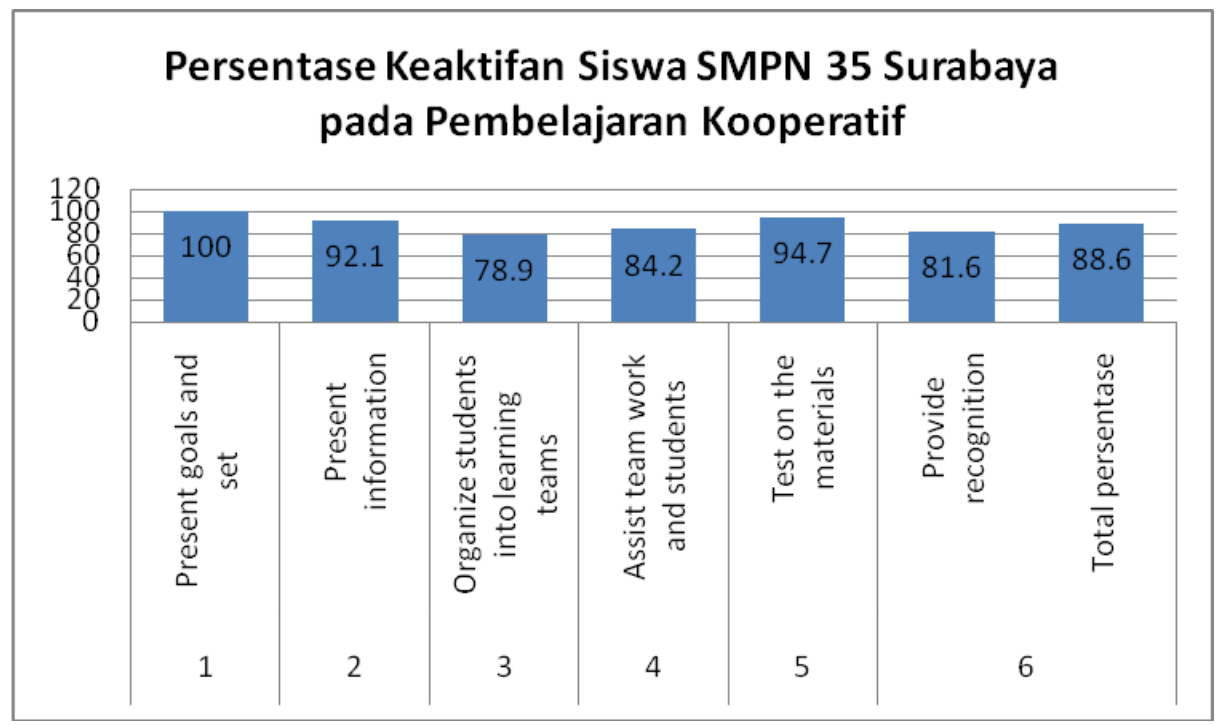

Gambar 1. Persentase Keaktifan Siswa

menonjolkan aktivitas siswa yang dominan dalam menyelesaikan suatu permasalahan secara aktif dengan bekerja sama.

Pembelajaran kooperatif adalah model pembelajaran yang berfokus pada penggunaan kelompok kecil siswa untuk bekerja sama dalam memaksimalkan kondisi belajar untuk mencapai tujuan belajar (Rofiq, 2010). Model pembelajaran cooperative learning tidak sama dengan sekedar belajar dalam ke lompok.

Ada lima unsur dasar pembelajaran cooperative learning yang membedakannya dengan pembagian kelompok yang dilakukan asal-asalan. Pelaksanaan model pembelajaran kooperatif dengan benar akan menunjukkan pendidik mengelola kelas lebih efektif.

Model pembe lajaran kooperatif ada lima unsur yaitu: saling ketergantungan positif, tanggung jawab perseorangan, tatap muka, komunikasi antar anggota, dan evaluasi proses kelompok. Pembelajaran kooperatif (Cooperative learning) adalah model pembelajaran yang menekankan pada saling ketergantungan positif antar individu siswa, adanya tanggung jawab perseorangan, tatap tugas anggota kelompok selama kegiatan. Keterampilan-keterampilan selama kooperatif tersebut antara lain sebagai berikut Lungdren,(1994) dalam Isjoni, (2010): 1) keterampilan kooperatif tingkat awal, 2) keterampilan kooperatif tingkat menengah, dan 3) keterampilan kooperatif tingkat mahir.

Pada keterampilan kooperatif tingkat awal, siswa dibimbing untuk menggunakan kesepakatan, menghargai kontribusi, mengambil giliran dan berbagi tugas, berada dalam kelompok, berada dalam tugas, mendorong partisipasi, mengundang orang lain, menyelesaikan tugas dalam waktunya, dan menghormati perbedaan individu.

Adapun keterampilan tingkat menengah meliputi menunjukan penghargaan dan simpati, mengungkapkan ketidaksetujuan dengan cara dapat diterima, mendengarkan dengan arif, bertanya, membuat ringkasan, menafsirkan, mengorganisir, dan mengurangi ketegangan.

Selanjutnya, keterampilan tingkat mahir meliputi, mengelaborasi, memeriksa dengan cermat, menanyakan kebenaran, menetapkan tujuan, dan berkompromi. 
Dari uraian diatas dapat disimpulkan karakteristik cooperative learning yaitu; a) setiap anggota memiliki peranan, b) terjadi hubungan interaksi langsung diantarasiswa, c) setiap anggota kelompok bertanggung jawab atas belajarnya dan juga teman-teman sekelompoknya, d) guru membantu mengembangkan keterampilan-keterampilan interpersonal kelompok, dan e) guru hanya berinteraksi dengan kelompok saat diperlukan.

Pembelajaran kooperatif menurut Slavin (2005) merujuk pada berbagai macam model pembelajaran di mana para siswa bekerja sama dalam kelompok-kelompok kecil yang terdiri dari berbagai tingkat prestasi, jenis kelamin, dan latar belakang etnik yang berbeda untuk saling membantu satu sama lain dalam mempelajari materi pelajaran.

Dalam kelas kooperatif, para siswa diharapkan dapat saling membantu, saling mendiskusikan, dan berargumentasi untuk mengasah pengetahuan yang mereka kuasai saat itu dan menutup kesenjangan dalam pemahaman masing-masing (Rofiq, 2010).

Pelaksanaan model cooperative learning membutuhakan partisipasi dan kerjasama dalam kelompok pembelajaran. Cooperative learning dapat meningkatkan cara belajar siswa menuju belajar lebih baik, sikap tolong menolong dalam beberapa prilaku sosial. Tujuan utama dalam penerapan model belajar mengajar cooverative learning adalah agar peserta didik dapat belajar secara berkelompok bersama dengan teman-temannya dengan cara saling menghargai pendapat dan memberikan kesempatan kepada orang lain untuk mengemukakan gagasannya dengan menyampaikan pendapat mereka secara berkelompok.

Pembelajaran kooperatif lebih dari sekedar belajar kelompok karena dalam model pembelajaran ini harus ada struktur dorongan dan tugas yang bersifat kooperatif sehingga memungkinkan terjadi interaksi secara terbuka dan hubungan-hubungan yang bersifat interdependensi efektif antara anggota kelompok.

Hartoto (2016) mengemukakan bahwa pembelajaran kooperatif adalah konsep yang lebih luas meliputi semua jenis kerja ke lompok termasuk bentuk-bentuk yang lebih dipimpin oleh guru atau diarahkan oleh guru. Menurut Trianto, (2007), Pembelajaran kooperatif merupakan sebuah kelompok strategi pengajaran yang melibatkan siswa bekerja secara berkolaborasi untuk mencapai tujuan bersama. Model pembelajaran kooperatif juga didefinisikan sebagai falsafah mengenai tanggung jawab pribadi dan sikapmenghormati sesama. Peserta didik bertanggung jawab atas belajar mereka sendiri dan berusaha menemukan informasi untuk menjawab pertanyaan-pertanyaan yang dihadapkan pada mereka.

Secara umum pembelajaran kooperatif dianggap lebih diarahkan oleh guru, di mana guru menetapkan tugas dan pertanyaanpertanyaan serta menyediakan bahan-bahan dan informasi yang dirancang untuk membantu siswa menyelesaikan masalah yang dimaksudkan. Guru biasanya menetapkan bentuk ujian tertentu pada akhir tugas (Paul, 2001)

Tujuan yang paling penting dari model pembelajaran kooperatif adalah untuk memberikan para siswa pengetahuan, konsep, kemampuan, dan pemahaman yang mereka butuhkan supaya bisa menjadi anggota masyarakat yang bahagia dan memberikan kontribus i.

Slavin (2005) mengemukakan bahwa tujuan model pembelajaran kooperatif adalah menciptakan norma-norma yang pro akademik di antara para siswa, dan norma-norma proakademik memiliki pengaruh yang amat penting bagi pencapaian siswa.

Dalam pembelajaran kooperatif, siswa tidak hanya mempelajari materi saja tetapi siswa atau peserta didik juga harus mempelajari keterampilan-keterampilan khusus yang disebut keterampilan kooperatif. Keterampilan kooperatif ini berfungsi untuk melancarkan hubungan kerja dan tugas. Peranan hubungan kerja dapat dibangun dengan membangun tugas anggota kelompok selama kegiatan pembelajaran.

Materi bilangan akar dan pangkat berisi tentang konsep yang sering dijumpai oleh siswa dalam kehidupan sehari-hari. Perkalian bilangan-bilangan dengan faktor-faktor yang sama disebut perkalian berulang. Setiap perkalian berulang dapat ditliskan secara ringkas dengan menggunakan notasi bilangan berpangkat. Adapun bilangan berpangkat sebenarnya karena bilangan-bilangan tersebut dapat dinyatakan dalam bentuk perkalian berulang. 
Bilangan berpangkat terdiri atas dua jenis, yaitu bilangan berpangkat negatif dan bilangan berpangkat positif. Selain itu, ada pula bilangan pecahan berpangkat dimana siswa dimbimbing untuk menentukan hasil pemangkatan bilangan pecahan berpangkat yang dapat digunakan dengan definisi bilangan berpangkat.

Selain itu, terdapat pula jenis bilangan rasional dan bilangan irrasional. Bilangan rasional ada lah bilangan yang dapat dinyatakan dalam bentuk, dengan $\mathrm{m}, \mathrm{n} \in \mathrm{B}$, dan $\mathrm{n} \neq 0$. Contoh bilangan rasional seperti 5, 3, dan seterusnya.

Sedangkan bilangan irrasional adalah bilangan riil yang tidak dapat dinyatakan dalam bentuk, dengan $\mathrm{m}, \mathrm{n} € \mathrm{~B}$ dan $\mathrm{n} \neq 0$. Bilangan-bilangan tersebut ternasuk bilangan irrasional karena hasil akar dari bilangan tersebut bukan merupakan bilangan rasional. Bilangan tersebut adalah bentuk akar, sehingga dapat disimpulkan bahwa bentuk akar adalah akar-akar dari suatu bilangan riil positif, yang hasilnya merupakan bilangan irrasional.

Untuk menuliskan jumlah tersebut terlalu panjang, dapat juga dituliskan dalam bentuk baku yaitu $1 \times 109$. Nah, bilangan yang dituliskan sebagai 109 inilah yang disebut sebagai bilangan berpangkat. Dalam hal ini 10 disebut bilangan pokok, sedangkan 9 disebut bilangan pangkat. Karena pangkatnya bilangan bulat, maka disebut bilangan berpangkat bilangan bulat.

Isjoni (2010) mengemukakan unsurunsur dalam pembelajaran kooperatif sebagai berikut; a. para siswa harus memiliki persepsi bahwa mereka " tenggelam atau berenang bersama"; b. para siswa harus memiliki tanggung jawab terhadap siswa atau siswa lain dalam kelompoknya, selain tanggung jawab terhadap diri sendiri dalam mempelajari materi yang dihadapi; c. para siswa harus berpendapat bahwa mereka semua memiliki tujuan yang sama; d. para siswa membagi tugas dan berbagi tanggung jawab di antara para anggota kelompok; e. para siswa diberikan satu evaluasi atau penghargaan yang akan ikut berpengaruh terhadap evaluasi kelompok $\mathrm{f}$. para siswa berbagi kepemimpinan sementara mereka memperoleh keterampilan bekerja sama selama belajar; g. setiap siswa akan diminta mempertanggung jawabkan secara individual materi yang ditangani dalam kelompok kooperatif.
Adapun Arends (2012) juga menyatakan bahwa tidak semua belajar kelompok bisa dianggap pembelajaran kooperatif. Untuk mencapai hasil yang maksimal, lima unsur dalam model pembelajaran kooperatif harus diterapkan. Lima uns ur tersebut adalah sebagai berikut. 1) Positive interdependence (saling ketergantungan positif). Unsur ini menunjukkan bahwa dalam pembelajaran kooperatif ada dua pertanggungjawaban kelompok. Pertama, mempelajari bahan yang ditugaskan kepada kelompok. Kedua, menjamin semua anggota kelompok secara individu mempelajari bahan yang ditugaskan tersebut.

Selanjutnya, adalah 2) Personal responsibility (tanggung jawab perseorangan). Pertanggungjawaban ini muncul jika dilakukan pengukuran terhadap keberhasilan kelompok. Tujuan pembelajaran kooperatif adalah membentuk semua anggota kelompok menjadi pribadi yang kuat. Tanggungjawab perseorangan adalah kunci untuk menjamin semua anggota yang diperkuat. Artinya, setelah mengikuti kelompok belajar bersama, anggota kelompok harus dapat menyelesaikan tugas yang sama. 3) Face to face promotive interaction (interaksi promotif) Unsur ini penting karena dapat menghasilkan saling ketergantungan positif. Ciri-ciri interaksi promotif adalah saling membantu secara efektif dan efisien, saling memberikan informasi dan sarana yang diperlukan, memproses informasi bersama secara lebih efektif dan efisien, saling mengingatkan, saling membanu dalam merumuskan dan mengembangkan argumentasi serta meningkatkan kemampuan wawasan terhadap masalah yang dihadapi, saling percaya, dan saling memotivasi untuk memperoleh keberhasilan bersama.

Selain ketiga di atas, 4) Interpersonal skill (komunikasi antaranggota) Untuk mengkoordinasikan kegiatan siswa dalam pencapaian tujuan siswa harus adalah saling mengenal dan mempercayai, mampu berkomunikasi secara akurat dan tidak ambisius, saling menerima dan saling mendukung, serta mampu menyelesaikan konflik secara konstruktif. 5) Group processing (pemrosesan kelompok). Pemrosesan mengandung arti menilai. Melalui pemrosesan kelompok dapat diidentifikasi dari urutan atau tahapan kegiatan kelompok dan 
kegiatan dari anggota kelompok. Siapa di antara anggota kelompok yang sangat membantu dan siapa yang tidak membantu. Tujuan pemrosesan kelompok adalah meningkatkan efektivitas anggota dalam memberikan kontribusi terhadap kegiatan kolaboratif untuk mencapai tujuan kelompok. Ada dua tingkat pemrosesan yaitu kelompok kecil dan kelas secara keseluruhan.

Pada dasarnya model cooperative learning dikembangkan untuk mencapai setidak-tidaknya tiga tujuan pembelajaran penting yang dirangkum Ibrahim, dkk (2000) dalam Isjoni, (2014 h.27) yaitu: 1) Hasil belajar akademik, Meningkatkan kinerja peserta didik dalam tugas-tugas akademik. Beberapa ahli berpendapat bahwa model ini unggul dalam membantu peserta didik memahami konsep-konsep yang sulit. 2) Penerimaan terhadap perbedaan individu, Penerimaan yang luas terhadap orang yang berbeda menurut ras, budaya, kelas sosial, kemampuan, maupun ketidakmampuan. Mengajarkan untuk saling menghargai satu sama lain. 3) Pengembangan keterampilan social, Mengajarkan kepada peserta didik keterampilan kerjasama dan kolaborasi. Keterampilan ini penting karena banyak anak muda dan orang dewasa masih kurang dalam keterampilan sosial.

Adapun ditemukann kelemahan pembelajaran kooperatif yang bersumber pada dua faktor, yaitu faktor dari dalam (intern) dan faktor dari luar (ekstern). Faktor dari dalam yaitu sebagai berikut. a. guru harus mempersiapkan pembelajaran secara matang, disamping itu memerlukan lebih banyak tenaga, pemikiran dan waktu; b. agar proses pembelajaran berjalan dengan lancar maka dibutuhkan dukungan fasilitas, a lat dan biaya yang cukup memadai; c. selama kegiatan diskusi kelompok berlangsung, ada kecenderungan topik permasalahan yang sedang dibahas meluas sehingga banyak yang tidak sesuai dengan waktu yang telah ditentukan, dan d. saat diskusi ke las, terkadang didominasi oleh seseorang, hal ini mengakibatkan siswa yang lain menjadi pasif.

Slavin (Miftahul, 2011: 68)

mengidentifikasi tiga kendala utama atau apa yang disebutnya pitfalls (lubang-lubang perangkap) terkait dalam pembelajaran kooperatif sebagai berikut. a. Free RiderJika tidak dirancang dengan baik, pembelajaran kooperatif justru berdampak pada munculnya free rider atau "pengendara bebas". Yang dimaksud free rider disini adalah beberapa siswa yang tidak bertanggung jawab secara personal pada tugas kelompoknya mereka hanya "mengekor" saja apa yang dilakukan oleh teman-teman satu kelompoknya yang lain. Free rider ini sering kali muncul ketika kelompok-kelompok kooperatif ditugaskan untuk menangani atu lembar kerja, satu proyek, atau satu laporan tertentu.

Untuk tugas-tugas seperti ini, sering kali ada satu atau beberapa anggota yang mengerjakan hampir semua pekerjaan kelompoknya, sementara sebagian anggota yang lain justru "bebas berkendara", berkeliaran kemana-mana.

Selanjutnya, b. Diffusion of responsibility. Yang dimaksud dengan diffusion of responsibility (penyebaran tanggung jawab) ini adalah suatu kondisi di mana beberapa anggota yang dianggap tidak mampu cenderung diabaikan oleh anggotaanggota lain yang "lebih mampu". Misalnya, jika siswa ditugaskan untuk mengerjakan tugas matematika, beberapa anggota yang dipersepsikan tidak mampu menghafal atau memahami materi tersebut dengan baik sering kali tidak dihiraukan oleh teman-temannya yang lain. Siswa yang memiliki skill matematis yang baik pun terkadang malas mengajarkan keterampilannya pada teman-temannya yang kurang mahir di bidang matematis logis.

Yang terakhir adalah c. Learning a Part of Task Specialization. Beberapa model pembelajaran tertentu, seperti Jigsaw, Group Investigation, dan metode-metode lain yang terkait, setiap kelompok ditugaskan untuk mempelajari atau mengerjakan bagian materi yang berbeda antarsatu sama lain. Pembagian semacam ini sering kali membuat siswa hanya fokus pada bagian materi lain yanng dikerjakan oleh kelompok lain hampir tidak dihiraukan sama sekali, padahal semua materi tersebut saling berkaitan satu sama lain.

Slavin (Miftahul, 2011:

mengemukakan bahwa ketiga kendala ini bisa diatasi jika guru mampu melakukan beberapa faktor sebagai berikut 1) mengenakan sedikit banyak karakteristik dan level kemampuan siswanya, 2) selalu menyediakan waktu khusus untuk mengetahui kemajuan setiap siswanya dengan mengevaluasi mereka secara individual setelah bekerja kelompok, dan yang paling 
penting 3) mengintegrasikan metode yang satu dengan metode yang lain.

Selain itu, Miftahul (2011) memaparkan beberapa aspek pembelajaran kooperatif sebagai berikut. a. Tujuan, Semua siswa ditempatkan dalam kelompok-kelompok kecil (sering kali yang beragam/ ability grouping/ heterogenous group) dan diminta untuk 1) mempelajari materi tertentu dan 2) saling memastikan semua anggota kelompok juga mempelajari materi tersebut. b. Level kooperatif, Kerja sama dapat diterapkan dalam kelas (dengan cara memastikan bahwa semua siswa di ruang kelas benar-benar mempelajari materi yang ditugaskan) dan level sekolah (dengan cara memastikan bahwa semua siswa di sekolah benar-benar mengalami kemajuan secara akademik).

Selanjutnya, adalah pola interaksi, Setiap siswa saling mendorong kesuksesan antarsatu sama lain. Siswa mempelajari materi pembelajaran bersama siswa lain, saling menjelaskan cara menyelesaikan tugas pembelajaran, saling menyimak penjelasan masingmasing, saling mendorong untuk bekerja keras, dan saling memberikan bantuan akademik jika ada yang membutuhkan. Pola interaksi ini muncul di dalam dan di antara kelompok-kelompok kooperatif. d. Evaluasi, Sistem evaluasi didasarkan pada kriteria tertentu. Penekanannya biasanya terletak pada pembelajaran dan kemajuan akademik setiap siswa, bisa pula difokuskan pada setiap kelompok, semua siswa, ataupun sekolah.

Dari uraian di atas, dapt disimpulkan bahwa pembelajaran kooperatif dirancang bagi tujuan untuk melibatkan pelajar secara aktif dalam proses pembelajaran melanjutkan perbincangan dengan teman-teman dalam kelompok kecil. Model ini juga memerlukan siswa bertukar pendapat, memberi tanya jawab serta mewujudkan serta membina proses penyelesaian kepada suatu masalah. Dapat dinyatakan bahwa pembelajaran kooperatif dapat memberikan hasil yang positif kepada siswa.

\section{SIMPULAN}

Berdasarkan hasil penelitian, dapat disimpulkan bahwa aktivitas siswa SMP dalam proses pembelajaran kooperatif pada mata pelajaran matematika termasuk ke dalam kriteria sangat baik, dengan persentase $88,6 \%$.

\section{DAFTAR PUSTAKA}

Anita, L. 2008. Cooperative Learning: Mempraktikkan Cooperative Learning di Ruang-Ruang Kelas. Jakarta: Grasindo.

Hartoto, T. (2016). Model Pembelajaran Kooperatif Tipe Group Investigation (Gi) Meningkatkan Aktivitas Dan Hasil Belajar Sejarah. Jurnal Historia, Vol.4, No.2, 2016.

Isjoni. 2010. Pembelajaran Kooperatif. Meningkatkan Kecerdasan Antar Peserta Didik. Yogyakarta: Pustaka Pelajar.

Isjoni. 2014. Cooperative Learning Efektivitas Pembelajaran Kelompok. Yogyakarta: Pustaka Pelajar

Jasmin. 2007. Panduan Praktis Mengajar Berbasis Multiple Intelligences. Bandung: Nuansa.

Martati, Badruli. 2010. Model Pembelajaran Kooperatif untuk Menumbuhkan Nilai Moral Siswa Sekolah Dasar. Bandung: Gresindo

Miftahul, Huda. 2011. Cooperative Learning. Yogyakarta: Pustaka Belajar

Nurhadi, 2003. Pembelajaran Kontekstual dan Penerapannya Dalam KBK. Malang: Universitas Negeri Malang.

Paul, S. 2001. Filsafat kontruktivisme dalam pendidikan. Yogyakarta: Kanisius.

Rofiq, M.N. (2010). Pembelajaran Kooperatif (Cooperative Learning) Dalam Pengajaran Pendidikan Agama Islam. Jurnal Falasifa, Vol. 1, No.1, 03-10.

Sardiman A. M. 2007. Interaksi Dan Motivasi Belajar Mengajar. Jakarta: PT. Raja Grafindo Persada. 2007.

Slameto, Alfabeta. 2003. Belajar dan Faktorfaktor yang Mempengaruhinya. Jakarta: PT. Rineka Cipta.

Slavin, R.E. 2009. cooverative lerning (teori, riset, praktik). Bandung: Nusa Media.

Syah, Muhibbin. 2002. Psikologi Pendidikan. Bandung: PT. Remaja Rosdakarya.

Trianto. 2007. Model-model Pembelajaran Inovatid Berorientasi Konstruktivistik. Jakarta: Prestasi Pustaka. 